\title{
MESIN PENGHALUS KULIT PISANG MENJADI BUBUK MINUMAN KOPI
}

\author{
Yudi Setiawan ${ }^{1}$ Saparin $^{2}$ ekasari wijianti ${ }^{3}$ \\ Teknik Mesin, Fakultas Teknik, Universitas Bangka Belitung \\ yudiubb@yahoo.co.id
}

\begin{abstract}
Abstrak
Penelitian ini tentang pemanfaatan kulit pisang kepok menjadi bubuk minuman kopi. Kulit pisang ini umumnya dihaluskan dengan menggunakan blender, namun kelemahannya adalah kapasitas produksinya lebih rendah, sehingga untuk memproduksi dalam jumlah banyak harus dilakukan proses berulang. Berdasarkan hal tersebut, maka dibuatlah sebuah mesin penghalus kulit pisang hingga menjadi bubuk dengan tingkat kehalusan bubuk kopi pada umumnya. Kulit pisang yang digunakan yaitu kulit pisang kepok matang. Proses penghalusan kulit pisang menggunakan mesin dengan menggunakan motor listrik sebesar $1 \frac{1}{2} \mathrm{HP}$, dengan putaran pada poros penghalus yaitu $1050 \mathrm{rpm}$. Hasil pengujian dengan bahan uji dengan massa 500 gram yaitu dalam waktu 1 menit menghasilkan 215 gram, waktu 2 menit menghasilkan 225,7 gram, waktu 3 menit menghasilkan 250,7 gram.
\end{abstract}

Kata Kunci : Mesin , Kulit pisang, Kopi

\begin{abstract}
This research is about the utilization of kepok banana peel into coffee drink powder. Banana peels are generally mashed using a blender, but the disadvantage is that the production capacity is lower, so to produce large quantities, a repeated process must be carried out. Based on this, a banana peel grinding machine was made to become a powder with the level of fineness of coffee grounds in general. The banana peel used is a ripe kepok banana peel. The process of refining banana peels uses a machine using an electric motor of $1 / 2 \mathrm{HP}$, with a rotation of $1050 \mathrm{rpm}$ on the smoothing shaft. The test results with the test material with a mass of 500 grams, which is within 1 minute to produce 215 grams, 2 minutes to produce 225.7 grams, 3 minutes to produce 250.7 grams
\end{abstract}

Keywords : Machine, Banana Peel, Coffee

\section{PENDAHULUAN}

Industri kuliner merupakan salah satu industri yang masih menempatkan diri sebagai industri strategis yang sangat menguntungkan. Kuliner sangat diminati oleh kebanyakan masyarakat karena memang merupakan kebutuhan pokok. Kuliner telah menjadi kontributor terbesar atau utama terhadap Produk Domestik Bruto (PDB) ekonomi kreatif Indonesia, yaitu sebesar 41 persen atau sebesar Rp 410 triliun (Rusiawan, 2019). Kuliner terkait erat dengan bidang pariwisata, karena salah satu pendukung pariwisata adalah keanekaragaman kuliner. Pada daerah-daerah wisata, hampir selalu ditemukan bermacam kuliner, bahkan kuliner itu sendiri adalah sebuah wisata bagi masyarakat. Menurut Bekraf (2019), data statistik ekonomi propinsi Kepulauan Bangka Belitung menyatakan bahwa dari 16 subsektor ekonomi kreatif yang ada, kuliner memegang rating paling tinggi, yaitu sebesar $68,45 \%$, diikuti bidang fashion $18,59 \%$. Bermacam cara mereka lakukan, baik dengan cara memodifikasi teknik pembuatan minuman kopi atau dengan mencampur beberapa bahan pendukung sehingga kopi disajikan dengan rasa yang unik. Selama ini, untuk menyajikan minuman kopi, bahan baku yang disajikan adalah bahan yang berasal dari bubuk buah kopi. Namun belakangan ini, ada hal menarik yang ditemukan oleh Imamah (2019). Imamah menyatakan bahwa untuk menyajikan minuman kopi yang enak dapat dibuat dari bahan lain, tidak selalu dari buah kopi, yaitu dari bahan kulit pisang. Supriyanti dkk, (2015) menyatkan bahwa kulit pisang kepok memiliki aktivitas antioksidan yang tinggi yaitu sebesar $95,14 \%$. Berdasarkan hal tersebut, dapat dikatakan bahwa kulit pisang kepok yang mengandung antioksidan tinggi, dapat diolah menjadi bubuk untuk disajikan menjadi minuman kopi. Alasan besar mengapa kulit pisang layak menggantikan minuman kopi adalah karena cita rasanya yang hampir menyamai kopi, selain itu pemilik kedai kopi tidak memerlukan modal yang besar untuk menyajikan minuman kopi, mereka dapat memanfaatkan kulit pisang tanpa biaya yang besar. Selama ini, kebanyakan masyarakat memanfaatkan kulit pisang sebagai pakan ternak atau

24 Setiawan, Yudi, dkk.; Mesin Penghalus Kulit Pisang Menjadi Bubuk Minuman Kopi 
membiarkannya menumpuk menjadi sampah sehingga mencemari lingkungan (Kholisoh, 2019). Potensi produksi buah pisang di indonesia tahun 2017 yaitu 7.162.678 Ton. Khususnya di Bangka Belitung (Babel) produksinya sebesar 4.734 ton, dengan pertumbuhan dari tahun 2016 sebesar 34,45\% dan luas panen pisang $73 \mathrm{Ha}$, mengalami peningkatan dibanding tahun 2016 sebesar 9,99\%. Produktifitas pisang di Bangka Belitung yaitu 65,05ton/ha (Kementan RI, 2018). Dengan potensi tersebut, menjadi peluang besar untuk memanfaatkan kulit pisang menjadi bubuk minuman kopi. Pengolahan kulit pisang menjadi menjadi bubuk kopi memiliki beberapa tahapan proses. Salah satu prosesnya yaitu proses penghalusan kulit pisang menjadi bubuk.

\section{METODOLOGI}

Pada penelitian ini menggunakan metode eksperimental, yaitu dengan merancang dan membangun mesin penghalus kulit pisang. Dimensi mesin secara keseluruhan dengan panjang $61 \mathrm{~cm}$, lebar $40 \mathrm{~cm}$, dan tinggi $88 \mathrm{~cm}$. Penelitian dilakukan dengan memvariasikan lama penghalusan 1,2 dan 3 menit. Adapun prosedur pengujiannya sebagai berikut:

Siapkan kulit pisang kepok yang sudah kering dan disangrai. Masing-masing sampel ditimbang dengan massa 500 gram per pengujian. Siapkan mesin penghalus kulit pisang kapok matang. Hubungkan mesin ke stopcontak.

Masukan kulit pisang kedalam tabung penghalusan berbarengan dengan menghidupkan stopwatch selama 1 menit. Matikan stopwatch saat waktu pengujian sudah mencapai 1 menit. Timbanglah bubuk kulit pisang yang keluar dari lubang pengeluaran tabung. Ulangi langkah langkah diatas, lakukanlah lagi untuk setiap variasi 2 menit dan 3 menit sebanyak 3 kali percobaan. Massa sampel tertinggal diperoleh dari selisih sampel percobaan dengan bubuk kopi yang keluar dari lubang pengeluaran tabung.

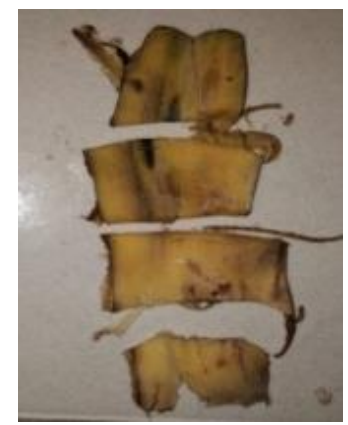

Gambar 1 Kulit pisang kepok dicacah

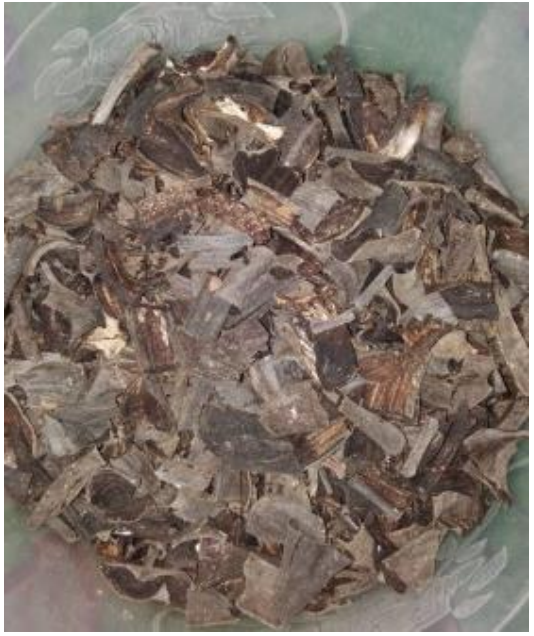

Gambar 2 Kulit pisang yang disangrai

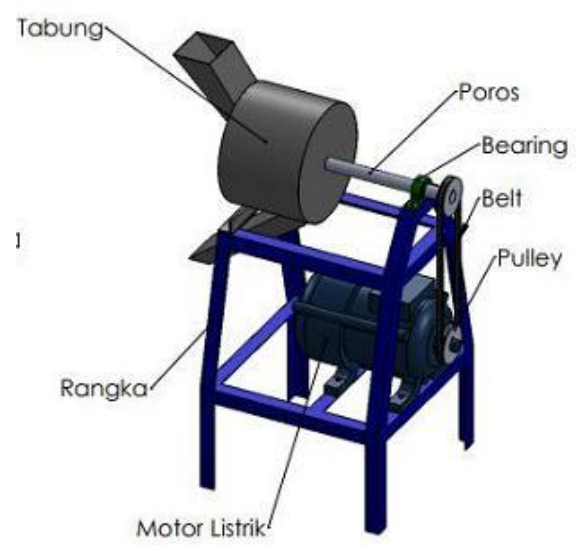

Gambar 3 Desain mesin

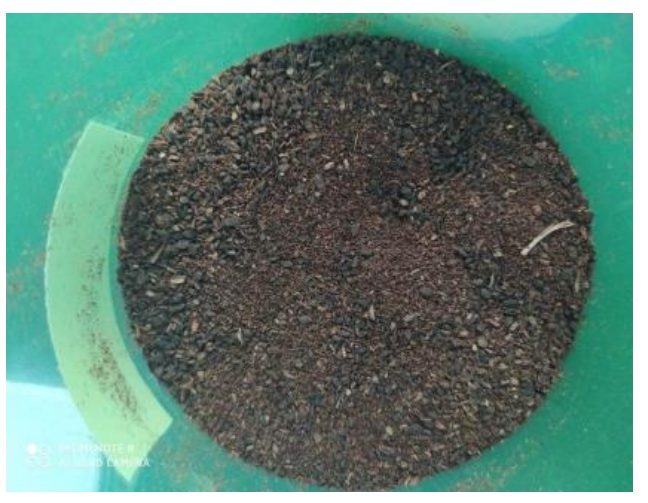

Gambar 4 Hasil pengujian dengan mesin

Bubuk kulit pisang yang dikatakan halus (H) jika lolos 86 mash. Bubuk kulit pisang yang lebih besar dari 86 mash dikatakan kurang halus $(\mathrm{KH})$. 


\section{HASIL DAN PEMBAHASAN}

\section{Hasil Pengujian}

Hasil pengujian yang dilakukan dengan cara melakukan pengujian dengan massa kulit pisang 500 Gram dengan 3 variasi 1 menit , 2 menit dan 3 menit proses penghalusan. Setiap waktu pengujian dilakukan 3 kali pengujian dengan massa 500 gram kulit pisang yang telah ditentukan. Tujuan dari pengujian yang dilakukan sebanyak 9 kali ingin mendapatkan rata-rata output terbaik dari 3 variasi waktu tersebut, berikut tabel hasil pengujian penghalusan kulit pisang dengan 3 variasi waktu dengan massa 500 gram kulit pisang sebagai berikut:

\section{Penghalusan kulit pisang Dengan Waktu 1 Menit}

Tabel 1 Penghalusan kulit pisang Dengan Waktu 1 Menit

\begin{tabular}{|l|l|l|l|l|l|}
\hline Waktu & $\begin{array}{c}\text { Massa } \\
\text { Awal }\end{array}$ & Sampel & H & KH & T \\
\hline 1 Menit & $500 \mathrm{Gram}$ & $\mathrm{A} 1$ & 233 & 250 & 17 \\
\hline 1 Menit & $500 \mathrm{Gram}$ & $\mathrm{A} 2$ & 218 & 268 & 14 \\
\hline 1 Menit & $500 \mathrm{Gram}$ & $\mathrm{A} 3$ & 194 & 282 & 24 \\
\hline Rata-rata & & 215 & 266,7 & 18,3 \\
\hline
\end{tabular}

Keterangan: H (Halus), KH (Kurang Halus), dan T (Terbuang)

Dari segi kapasitas output pada mesin penghalus kulit pisang akan dihitung rata-rata keberhasilan mesin dengan sampel kulit pisang halus sebagai berikut :

Kapasitas rata-rata dalam waktu 1 menit

$$
\begin{aligned}
& =\frac{A 1+A 2+A 3}{\text { Jumlah Sample }} \\
& =\frac{231+219+195}{3} \\
& =215 \frac{\text { gram }}{\text { menit }}
\end{aligned}
$$

Efisiensi produksi mesin

$$
=\frac{215}{500} \times 100 \%=43 \% \text {. }
$$

Dari Tabel 1 dapat disimpulkan bahwa ratarata massa kulit pisang halus yang dapat dihaluskan oleh mesin penghalus kulit pisang dengan massa 500 gram dalam waktu 1 menit dengan jumlah 3 sampel pengujian adalah 215 gram/menit kulit pisang yang halus, dan rata-rata kulit pisang yang kurang halus 266,7 gram/menit sedangkan rata-rata kulit pisang yang terbuang adalah $18,3 \mathrm{gram} / \mathrm{menit}$. Untuk efisiensi pengujian dengan waktu 1 menit hanya mencapai $43 \%$.

\section{Penghalusan kulit pisang Dengan Waktu 2 Menit}

Tabel 2Penghalusan kulit pisang 500 Gram Dengan Waktu 2 Menit

\begin{tabular}{|l|l|l|l|l|l|}
\hline Waktu & Massa Awal & Sampel & H & KH & T \\
\hline 2 Menit & 500 Gram & A1 & 234 & 246 & 20 \\
\hline 2 Menit & 500 Gram & A2 & 206 & 282 & 12 \\
\hline 2 Menit & 500 Gram & A3 & 237 & 247 & 16 \\
\hline Rata-rata & & 225,7 & 258,3 & 16 \\
\hline
\end{tabular}

Keterangan: H (Halus), KH (Kurang Halus), dan T (Terbuang)

Dari segi kapasitas output pada mesin penghalus kulit pisang akan dihitung rata-rata keberhasilan mesin dengan sampel kulit pisang halus sebagai berikut :

Kapasitas rata-rata dalam waktu 2 menit

$$
\begin{aligned}
& =\frac{A 1+A 2+A 3}{\text { Jumlah Sample }} \\
& =\frac{234+207+236}{3} \\
& =225,7 \frac{\mathrm{gram}}{2 \mathrm{menit}} \\
& =112.85 \frac{\mathrm{gram}}{\text { menit }}
\end{aligned}
$$

Efisiensi produksi mesin

$$
=\frac{225,7}{500} \times 100 \%=45,14 \%
$$

Dari Tabel 2 dapat disimpulkan bahwa ratarata massa kulit pisang halus yang dapat dihaluskan oleh mesin penghalus kulit pisang dengan massa 500 gram dalam waktu 2 menit dengan jumlah 3 sampel pengujian adalah 112,85 gram/menit kulit pisang yang halus, dan rata-rata kulit pisang yang kurang halus 129,15 gram/menit sedangkan rata-rata kulit pisang yang terbuang adalah 8 gram/menit. Untuk efisiensi pengujian dengan waktu 2 menit hanya mencapai $45,14 \%$.

\section{Penghalusan kulit pisang Dengan Waktu 3 Menit}

Tabel 3 Penghalusan kulit pisang Dengan Waktu 3 Menit

\begin{tabular}{|l|l|l|l|l|l|}
\hline Waktu & Massa Awal & Sampel & \multicolumn{1}{c|}{ H } & \multicolumn{1}{c|}{ KH } & T \\
\hline 3 Menit & 500 Gram & A1 & 243 & 239 & 18 \\
\hline 3 Menit & 500 Gram & A2 & 239 & 245 & 16 \\
\hline 3 Menit & 500 Gram & A3 & 270 & 213 & 17 \\
\hline Rata-rata & & 250,7 & 232,3 & 17 \\
\hline
\end{tabular}

Keterangan: H (Halus), KH (Kurang Halus), dan T (Terbuang)

Dari segi kapasitas output pada mesin penghalus kulit pisang akan dihitung rata-rata keberhasilan mesin dengan sampel kulit pisang halus sebagai berikut :

Kapasitas rata-rata dalam waktu 3 menit

$$
=\frac{A 1+A 2+A 3}{\text { Jumlah Sample }} \text {. }
$$




$$
\begin{aligned}
& =\frac{244+238+270}{3} \\
& =250,7 \frac{\mathrm{gram}}{3 \mathrm{menit}} \\
& =83,57 \frac{\mathrm{gram}}{\text { menit }}
\end{aligned}
$$

Efisiensi produksi mesin

$$
=\frac{250,7}{500} \times 100 \%=50,14 \%
$$

Dari Tabel 3 dapat disimpulkan bahwa ratarata massa kulit pisang halus yang dapat dihaluskan oleh mesin penghalus kulit pisang dengan massa 500 gram dalam waktu 3 menit dengan jumlah 3 sampel pengujian adalah 83,57 gram/menit kulit pisang yang halus, dan rata-rata kulit pisang yang kurang halus 77,43 gram/menit sedangkan rata-rata kulit pisang yang terbuang adalah 5,67 gram/menit. Untuk efisiensi pengujian dengan waktu 3 menit hanya mencapai $50,14 \%$.

Hasil pengujian dengan 3 variasi waktu 1,2 dan 3 menit dengan massa 500 gram kulit pisang dengan standar ukuran butiran pengayakan 18 mesh dapat dilihat dalam bentuk grafik pada gambar 4.3

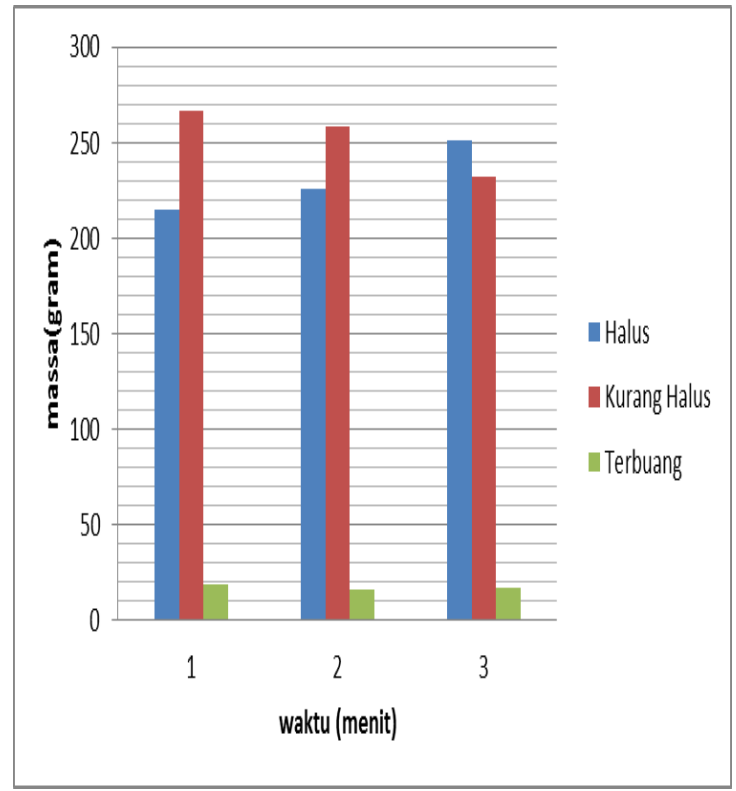

\section{Gambar 5 Produksi Mesin Penghalus kulit pisang}

2. Efisiensi Produksi Mesin Penghalus kulit pisang Berdasarkan pengujian mesin penghalus kulit pisang dengan massa 500 gram dilakukan 3 variasi waktu yaitu 1 menit, 2 menit, dan 3 menit. Untuk pengujian 1 menit. untuk efisiensi produksi mesin semakin lama waktu proses penghalus maka akan semakin tinggi tingkat efisiensi produksi pada mesin modifikasi penghalus kulit pisang dengan hasil output melewati proses pengayakan dengan standar 18 mesh.

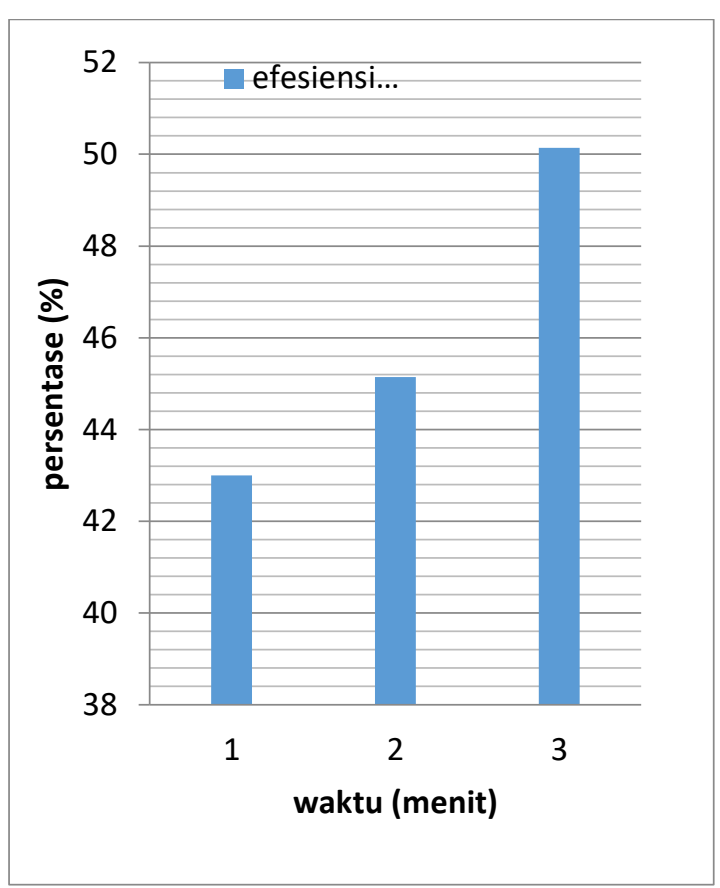

Gambar 6 Efisiensi Produksi Mesin

\section{KESIMPULAN}

Rata-rata massa kulit pisang halus yang dapat dihaluskan oleh mesin penghalus kulit pisang dengan massa 500 gram dalam waktu 1 menit adalah 215 gram, waktu 2 menit menghasilkan 225,7 gram 250, waktu 3 menit menghasilkan 250,7 gram.

\section{UCAPAN TERIMA KASIH}

Ucapan terimakasih penulis sampaikan kepada pihak Universitas Bangka Belitung yang telah mendanai penelitian ini lewat skema Penelitian Dosen Tingkat Jurusan tahun 2020.

\section{DAFTAR PUSTAKA}

[1] Badan Ekonomi Kreatif Indonesia.2019. Tonggak Baru Ekonomi Kreatif Indonesia. Badan Ekonomi Kreatif Indonesia. 2019. Infografis Sebaran Pelaku Ekonomi Kreatif.

[2] Imamah, Fitria Nurul. 2019. Sulap Kulit Pisang Jadi Kopi Mahasiswa Pekerjakan Tetangga. Radar madura. https://radarmadura.jawapos.com /read/2019/09/25/157511/sulap-kulit-pisang-jadi kopi-mahasiswi-pekerjakan -tetangga diakses 3 maret 2020

[3] Kholisoh, Siti Nur. 2019. Kopi Kulit Pisang Kaya Antioksi dan: solusi bagi penikmat kopi 
yang phobia cafein. (https://warstek.com/2019/08/05/kulitpisang/dia kses 3 maret 2020.

[4] Rusiawan, Wawan. 2019. Industri Kuliner Jadi Penopang Terbesar Perekonomian Kreatif Indonesia, disampaikan dalam seminar keunggulan kuliner indonesia 2019 yang diselenggarakan oleh FTP UGM dan Direktorat Penelitian dan Pengabdian kepada Masyarakat
UGM bekerjasama dengan Bekraf di FTP UGM 4-5 September 2019.

[5] Supriyanti, F.M.T., Suanda, H., Dan Rosdiana, R. 2015. Pemanfaatan Ekstrak Kulit Pisang Kepok (Musa bluggoe) Sebagai Sumber Antioksidan pada Produksi Tahu. Seminar Nasional Kimia dan Pendidikan Kimia VII. Universitas Sebelas Maret Surakarta, pp 393-400 